\title{
$\beta$-Adrenergic signaling in rat heart is similarly affected by continuous and intermittent normobaric hypoxia
}

\author{
Klara Hahnova ${ }^{1}$, Dita Kasparova ${ }^{1}$, Jitka Zurmanova ${ }^{1}$, Jan Neckar², Frantisek Kolar² \\ and Jiri Novotny ${ }^{1}$ \\ ${ }^{1}$ Department of Physiology, Faculty of Science, Charles University in Prague, Prague, Czech Republic \\ ${ }^{2}$ Department of Developmental Cardiology, Institute of Physiology, Czech Academy of Sciences, Prague, Czech Republic
}

\begin{abstract}
Chronic hypoxia may produce a cardioprotective phenotype characterized by increased resistance to ischemia-reperfusion injury. Nevertheless, the molecular basis of cardioprotective effects of hypoxia is still not quite clear. The present study investigated the consequences of a 3-week adaptation to cardioprotective ( $\mathrm{CNH}$, continuous normobaric hypoxia) and nonprotective (INH, intermittent normobaric hypoxia; $23 \mathrm{~h} /$ day hypoxia followed by $1 \mathrm{~h} /$ day reoxygenation) regimen of hypoxia on $\beta$-adrenergic signaling in the rat myocardium. Both regimens of hypoxia lowered body weight and led to marked right ventricular (RV) hypertrophy, which was accompanied by $25 \%$ loss of $\beta 1$-adrenergic receptors ( $\beta 1$-ARs) in the RV. No significant changes were found in $\beta$-ARs in left ventricular (LV) preparations from animals adapted to hypoxia. Although adenylyl cyclase (AC) activity stimulated through the G proteins was decreased in the RV and increased in the $\mathrm{LV}$ after exposure to hypoxia, there were no significant changes in the expression of the dominant myocardial AC 5/6 isoforms and the stimulatory G proteins. These data suggest that chronic normobaric hypoxia may strongly affect myocardial $\beta$-adrenergic signaling but adaptation to cardioprotective and nonprotective regimens of hypoxia does not cause notably diverse changes.
\end{abstract}

Key words: Rat myocardium - Chronic hypoxia $-\beta$-adrenergic receptors - Adenylyl cyclase

Abbreviations: AC, adenylyl cyclase; $\beta$-ARs, $\beta$-adrenergic receptors; BSA, bovine serum albumin; $\mathrm{CNH}$, continuous normobaric hypoxia; EDTA, ethylenediaminetetraacetic acid; INH, intermittent normobaric hypoxia; LV, left ventricle; RV, right ventricle.

\section{Introduction}

Hypoxia can evoke different effects, either adaptive or pathological, depending on the severity, pattern, and duration of exposure. Chronic hypoxia has been found to induce a wide range of adaptive changes in the heart, which could be considered as cardioprotective. Adaptation of myocardium to certain regimens of chronic hypoxia can contribute to the improvement of ischemic tolerance and enhancement of left ventricular contractility in heart failure (Zhuang and Zhou 1999; Ostadal and Kolar 2007; Naghshin et al. 2012). Chronic

Correspondence to: Jiri Novotny, Department of Physiology, Faculty of Science, Charles University in Prague, Prague, Czech Republic

E-mail: jiri.novotny@natur.cuni.cz hypoxia leads to increased activity of the sympathetic nervous system, thus increasing catecholamine levels in the body. The increased level of catecholamines and their effect on $\beta$-adrenergic signaling could contribute to the development of a cardioprotective phenotype (Mallet et al. 2006). Nevertheless, the exact molecular mechanisms underlying hypoxia-induced cardioprotection are still unclear.

Chronic hypoxia leads to pulmonary hypertension and subsequently to the right ventricular (RV) hypertrophy. The left ventricle (LV) usually does not hypertrophy unless at rather severe and prolonged intermittent hypoxia (Pelouch et al. 1997). Besides increased tolerance to an acute ischemic injury, animals adapted to chronic hypoxia exhibit the impaired chronotropic and inotropic responsiveness to $\beta$-adrenergic stimulation (Pei et al. 2000). We have previously shown that severe chronic intermittent 
high-altitude hypoxia deranges myocardial adenylyl cyclase (AC) signaling in both ventricles (Hrbasova et al. 2003). A number of earlier studies reported down-regulation of $\beta$-adrenoceptors ( $\beta$-ARs) and desensitization of AC in the hypoxic heart (Mader et al. 1991; Mardon et al. 1998; Leon-Velarde et al. 2001). All these changes may reflect increased sympathetic activity under hypoxic conditions. However, the concequencess of chronic hypoxia may differ in different experimental settings as illustrated by increased expression of $\beta$-ARs and unchanged AC activity in isolated cardiac myocytes ( $\mathrm{Li}$ et al. 1996).

There are some indications that $\beta$-adrenergic signaling may play a role in cardioprotection. The engagement of $\beta$-ARs in the induction of a cardioprotective phenotyp has been demonstrated by administration of metoprolol to dogs throughout their exposure to intermittent hypoxia. This $\beta_{1}$-AR antagonist markedly blunted hypoxia-evoked cardioprotection (Mallet et al. 2006). Okruhlicova et al. (1999) reported the involvement of AC in mechanisms underlying ischemic preconditioning in the rat heart. We and others have previously observed certain changes in the stimulatory $G$ proteins (Gs) of animals exposed to chronic hypoxia. Whereas Pei et al. (2000) reported oposite changes in the short and long Gsa isoforms in ventricular myocytes isolated from hypoxia-exposed rats, we noticed a sligh increase in cytosolic but not membrane-bound Gsa (Hrbasova et al. 2003). There were no significant changes in the amount of the inhibitory $\mathrm{G}$ proteins (Gi) after adaptation to hypoxia. The discordant data on gene expression, protein levels, and their functional activity do not provide a clear evidence for the role of trimeric $G$ proteins in the cardioprotective mechanisms. Anyway, the stimulatory and inhibitory $\mathrm{G}$ proteins are key regulatory elements of the $\beta$-adrenergic signaling pathway which modulate the enzyme activity of AC under variable physiological conditions (El-Armouche et al. 2003). Besides Ga subunits, also $G \beta \gamma$ subunits may regulate isoform-dependent AC activity. The dominant cardiac AC isoforms ( 5 and 6) are known to be inhibited by $\mathrm{G} \beta \gamma$ (Beazely and Watts 2006).

Many investigators tested different regimens of chronic hypoxia for their cardioprotective effects in the past. Apparently, both continuous and intermittent hypoxia can enhance cardiac ischemic tolerance under certain conditions (Neckar et al. 2002; Guo et al. 2009; Maslov et al. 2013). However, the outcome obviously depends not only on the degree and duration of hypoxia, but also on the number, duration and periodicity of daily normoxic episodes. Interestingly, it was recently demonstrated that a brief daily episode of reoxygenation can abolish cardioprotection conferred by adaptation to chronic normobaric hypoxia. Daily reoxygenation eliminated both the infarct size-limiting effect of continuous hypoxia in open-chest rats subjected to coronary artery occlusion and cytoprotective effects of hypoxic adaptation in isolated ventricular myocytes exposed to acute anoxic insult (Neckar et al. 2013). So far, there is no information about the possible difference between the effect of protective and nonprotective regimens of hypoxia on the myocardial $\beta$-adrenergic signaling system that might potentially contribute to diverse ischemic tolerance. Therefore, the present study was aimed to evaluate the presumed impact of protective continuous $(\mathrm{CNH})$ and nonprotective intermittent (INH) normobaric hypoxia on $\beta$-adrenergic signaling in the RV and LV myocardium of adult rats. We have assessed the distribution of $\beta$-ARs receptors, $G$ proteins and $A C$, as well as functional status of this crucial myocardial signaling system.

\section{Materials and Methods}

\section{Materials}

TRIzol Reagent was from Invitrogen (Carlsbad, CA, USA), $\left[a-{ }^{32} \mathrm{P}\right]$ ATP, $\left[{ }^{3} \mathrm{H}\right] \mathrm{cAMP}$ and $\left[{ }^{3} \mathrm{H}\right] \mathrm{CGP} 12177$ were purchased from Amersham Biosciences (Buckinghamshire, UK) and scintillation cocktail CytoScint from ICN Biomedicals (Irvine, CA, USA). Acrylamide and bis-acrylamide were from SERVA (Heidelberg, Germany), aluminum oxide 90 (neutral, activity I) was from Merck (Darmstadt, Germany) and Protran nitrocellulose transfer membranes were from Schleicher \& Schuell BioScience (Dassel, Germany). All other chemicals were from Sigma (St. Louis, MI, USA) and they were of the highest purity available.

\section{Animal model}

Adult male Wistar rats (Velaz, Ltd., Czech Republic) with initial body weight (BW) about $280 \pm 15 \mathrm{~g}$ were used throughout the study. Animals were fed an ad libitum standard chow diet and kept 3 per cage in a controlled environment $\left(23^{\circ} \mathrm{C}\right.$, $12 \mathrm{~h}: 12 \mathrm{~h}$ light-dark cycle). One group of rats was exposed to continuous normobaric hypoxia $\left(\mathrm{CNH}, 24 \mathrm{~h} /\right.$ day, 10\% $\left.\mathrm{O}_{2}\right)$ for 3 weeks in a chamber equipped with hypoxic generators (Everest Summit, Hypoxico Inc., NY, USA). The chamber construction allowed for regular animal maintenance without any reoxygenation during this period. Another group of rats was exposed to hypoxia intermittently (INH, $23 \mathrm{~h}$ /day) with single $1 \mathrm{~h}$ /day episod of normoxia (room air) during 3 weeks of adaptation. A control group (N) was kept at room air for the same period of time. All animal experiments were approved by the Institutional Animal Use and Care Committee of the Institute of Physiology, Czech Academy of Sciences (No. 140/2011). Rats were maintained according to the Guide for the Care and Use of Laboratory Animals published by the US National Institutes of Health (NIH Publication No. 85-23, revised 1996). 


\section{Processing of heart tissue for biochemical analyses}

After sacrifying the rats by decapitation, hearts were rapidly excised and washed in ice-cold saline solution. The LV and RV free walls were dissected from the septum, immediately frozen in liquid nitrogen and weighed. The pieces of frozen tissue were homogenized either in TRIzol Reagent for isolation of mRNA or in homogenization buffer $\mathrm{H}$ (20 mM Tris, $3 \mathrm{mM} \mathrm{MgCl}_{2}, 0.25 \mathrm{M}$ sucrose, $1 \mathrm{mM}$ EDTA and protease inhibitor cocktail (Complete, Roche Diagnostics); pH 7.4) for radioligand binding assay, Western blotting and enzyme activity analysis. In the latter case, the rat ventricles were homogenized for $1 \mathrm{~min}$ on ice using a motor-driven homogenizer (Teflon-glass). The homogenates were subsequently clarified by centrifugation at $600 \times g$ for $10 \mathrm{~min}\left(4^{\circ} \mathrm{C}\right)$ in order to remove nuclei and particulate cellular debris. Thereafter, the resulting postnuclear supernatant was centrifuged at $50000 \times g$ for $30 \mathrm{~min}\left(4^{\circ} \mathrm{C}\right)$ in order to isolate crude membranes. The pellet containing crude membranes was resuspended in TME buffer $\left(20 \mathrm{mM}\right.$ Tris, $3 \mathrm{mM} \mathrm{MgCl}_{2}$ and $1 \mathrm{mM}$ EDTA; $\mathrm{pH} 7.4$ ), aliquoted and stored at $-80^{\circ} \mathrm{C}$ until use.

\section{Real-time PCR analysis}

Total cellular RNA was extracted from samples of the individual ventricles using TRIzol Reagent. One microgram of total RNA was converted to cDNA using oligo(dT) primers and RevertAid ${ }^{\mathrm{TM}} \mathrm{H}$ Minus First Strand cDNA Synthesis Kit (Fermentas UAB, Vilnius, Lithuania) according to manufacturer's protocol. Real-time PCR protocol was performed on a LightCycler 480 (Roche Applied Sciences, Penzberg, Germany) using a MESA GREEN qPCR MasterMix Plus for SYBR Assay No ROX (Eurogentec, Belgium) according to the manufacturer's protocol. Genespecific primer pairs for $\beta$-adrenergic receptors were designed using the Universal Probe Library Assay Design Center (UPL, Roche Applied Science) and the sequences of forward and reverse primers were: 5 '-AGAGCAGAAGGCGCTCAAG-3' and 5'-AGCCAGCAGAGCGTGAAC-3' for $A d r B 1$, and 5'-ACGAGCTCAGTGTGCAGGA-3' and 5'-TCCTGGAAGCTTCATTCAGAG-3' for AdrB2. The levels of analyzed transcripts were quantified after normalization to the level of hypoxanthine-guanine phosphoribosyltransferase 1 (Hprt1) reference gene transcript (Waskova-Arnostova et al. 2013). All measurements were performed in triplicates.

\section{$\beta$-Adrenergic receptor binding}

Myocardial $\beta$-ARs were determined by radioligand binding assay with the $\beta$-antagonist $\left[{ }^{3} \mathrm{H}\right] \mathrm{CGP} 12177$ as described previously (Klevstig et al. 2013). Briefly, samples of myocardial membranes (100 $\mu$ g protein) were incubated in a buffer
B (50 mM Tris- $\mathrm{Cl}, 10 \mathrm{mM} \mathrm{MgCl} 2$ and $1 \mathrm{mM}$ ascorbic acid; $\mathrm{pH} 7.4$ ) containing $4 \mathrm{nM}\left[{ }^{3} \mathrm{H}\right] \mathrm{CGP} 12177$ at $37^{\circ} \mathrm{C}$ for $1 \mathrm{~h}$ (total volume of $0.5 \mathrm{ml})$. The binding reaction was terminated by adding $3 \mathrm{ml}$ of ice-cold buffer $\mathrm{C}(50 \mathrm{mM}$ Tris- $\mathrm{Cl}$ and $10 \mathrm{mM} \mathrm{MgCl}_{2} ; \mathrm{pH}$ 7.4) and subsequent filtration through GF/C filters presoaked for $1 \mathrm{~h}$ with polyethylenimine. The filters were then washed 2 times with $3 \mathrm{ml}$ of ice-cold buffer C. After addition of $4 \mathrm{ml}$ scintillation cocktail CytoScint, radioactivity retained on the filters was measured by counting for $5 \mathrm{~min}$. Nonspecific binding was defined as that not displaceable by $10 \mu \mathrm{M}$ L-propranolol and it represented about $30 \%$ of total binding. For competition experiments, samples were incubated with $1 \mathrm{nM}\left[{ }^{3} \mathrm{H}\right] \mathrm{CGP} 12177$ and increasing concentrations of the selective $\beta_{2}$-AR antagonist ICI 118.551 $\left(10^{-4}-10^{-10} \mathrm{M}\right)$. The characteristics of $\beta$-adrenergic binding sites and the $\beta_{1}$ - and $\beta_{2}$-AR proportions in myocardial membranes were calculated using GraphPad Prism 6 software (GraphPad Software, La Jolla, CA, USA).

\section{Electrophoresis and Western blotting}

Samples of myocardial membranes were solubilized (3:1) in Laemmli buffer and loaded $(30 \mu \mathrm{g}$ per lane) on standard ( $10 \%$ acrylamide $0.26 \%$ bis-acrylamide) polyacrylamide gels (Novotny et al.2001). SDS-PAGE was carried out at $200 \mathrm{~V}$ for 60 min on a Mini-Protean II apparatus (BIO-RAD, Hercules, CA, USA). After electrophoresis, the resolved proteins were transferred to nitrocellulose membrane (Schleicher \& Schuell), blocked with 5\% non-fat dry milk in TBS buffer (10 mM Tris, $150 \mathrm{mM} \mathrm{NaCl}$; $\mathrm{pH}$ 8.0) for $1 \mathrm{~h}$ and then incubated with relevant primary antisera (all antibodies were purchased from Santa Cruz Biotechnology, Inc., Santa Cruz, CA, USA) overnight at room temperature. After washing in TBS containing $0.3 \%$ Tween 20 , the membranes were incubated with secondary anti-rabbit IgG labeled with horseradish peroxidase for $1 \mathrm{~h}$. Immunoreactive proteins on the blots were visualized by enhanced chemiluminiscence technique according to the manufacture's instructions (Pierce Biotechnology, Rockford, IL, USA) and quantitatively analyzed by the ImageQuant program (Molecular Dynamics, Sunnyvale, CA, USA). To correct for errors associated with sample loading and gel transfer, $\beta$-actin was used as a housekeeping protein for reliable quantification of Western blot data.

\section{Determination of adenylyl cyclase activity}

Activity of AC was determined as described previously (Ihnatovych et al. 2001). Briefly, the reaction mixture (in a total volume of $0.1 \mathrm{ml}$ ) contained $20 \mu \mathrm{g}$ of protein, $48 \mathrm{mM}$ Tris- $\mathrm{HCl}$ buffer ( $\mathrm{pH}$ 7.4), $100 \mathrm{mM} \mathrm{NaCl}, 2 \mathrm{mM} \mathrm{MgCl}$, $1 \mathrm{mM}$ EDTA, $3.2 \mathrm{U} / \mathrm{ml}$ pyruvate kinase, $5 \mathrm{mM}$ potassium phosphoenolpyruvate, $0.8 \mathrm{~g} / \mathrm{ml} \mathrm{BSA}, 40 \mu \mathrm{M} 3$-isobutyl-1methylxanthine, $20 \mu \mathrm{M}$ GTP, $0.1 \mathrm{mM}$ cAMP, $15000 \mathrm{cpm}$ 
A
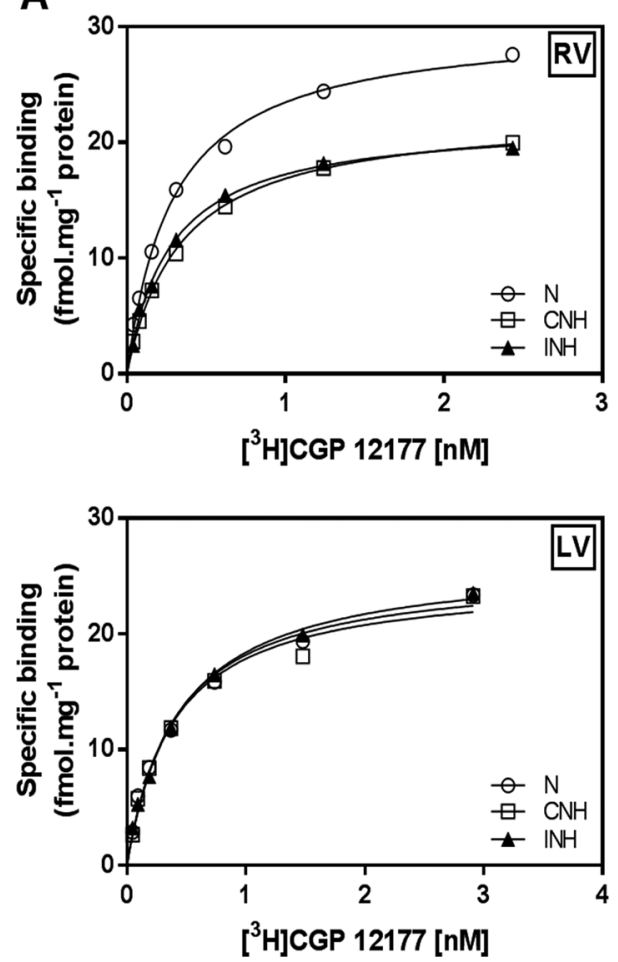

B
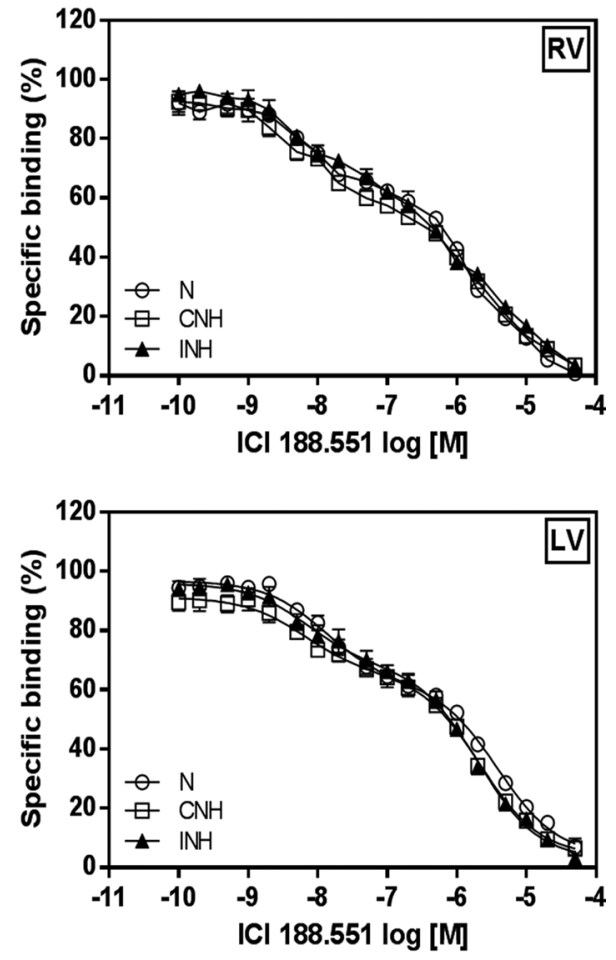

Figure 1. Characterization of $\beta$-adrenoceptors in right (RV) and left (LV) ventricular preparations from rats exposed to $\mathrm{CNH}$ (open squares) or INH (closed triangles) and in corresponding normoxic controls (open circles). Shown are representative $\left[{ }^{3} \mathrm{H}\right]$ CGP12177 saturation binding curves (A) and competitive binding curves which were constructed using the $\beta_{2}$-AR antagonist ICI 188.551 (B). Data represent means ( \pm S.E.M.) of three separate experiments performed in triplicates. $\mathrm{N}$, normoxia; $\mathrm{CNH}$, continuous normobaric hypoxia; $\mathrm{INH}$, intermittent normobaric hypoxia. per sample of $\left[{ }^{3} \mathrm{H}\right] \mathrm{cAMP}$ and $0.4 \mathrm{mM}$ ATP with $\left[\mathrm{a}^{-32} \mathrm{P}\right] \mathrm{ATP}$ (about $1 \times 10^{6} \mathrm{cpm}$ per sample). For stimulation of AC, the following stimulators were used in separate experiments: $10 \mu \mathrm{M}$ isoprenaline, $10 \mu \mathrm{M}$ forskolin, $100 \mu \mathrm{M}$ GTP $\gamma \mathrm{S}, 10 \mathrm{mM}$ $\mathrm{MnCl}_{2}$ and $10 \mathrm{mM} \mathrm{NaF}$. After $1 \mathrm{~min}$ preincubation $0.4 \mathrm{mM}$ ATP was added along with $200,000 \mathrm{cpm}\left[\alpha^{32} \mathrm{P}\right]$ ATP and incubation proceeded for $20 \mathrm{~min}$ at $30^{\circ} \mathrm{C}$. The reaction was terminated by adding $0.2 \mathrm{ml}$ of $0.5 \mathrm{M} \mathrm{HCl}$ and heating for $5 \mathrm{~min}$ at $100^{\circ} \mathrm{C}$. The cyclic AMP formed was separated by alumina columns and the detected amount of $\left[{ }^{32} \mathrm{P}\right] \mathrm{cAMP}$ corrected for recovery with $\left[{ }^{3} \mathrm{H}\right]$ cAMP.

Table 1. Weight parametres

\begin{tabular}{lccc}
\hline & \multicolumn{3}{c}{ Group } \\
\cline { 2 - 4 } & $\mathrm{N}(n=10)$ & $\mathrm{CNH}(n=10)$ & $\mathrm{INH}(n=10)$ \\
\hline Body weight $(\mathrm{g})$ & $359.9 \pm 8.3$ & $305.3 \pm 7.7^{*}$ & $309.9 \pm 6.9^{*}$ \\
Heart weight $(\mathrm{mg})$ & $836.4 \pm 20.9$ & $936.4 \pm 43.3^{*}$ & $971.8 \pm 56.5^{*}$ \\
RV weight $(\mathrm{mg})$ & $185.0 \pm 5.9$ & $314.4 \pm 15.5^{*}$ & $343.4 \pm 27.6^{*}$ \\
LV weight $(\mathrm{mg})$ & $452.9 \pm 15.1$ & $442.5 \pm 22.4$ & $441.7 \pm 26.2$ \\
RV/BW $\left(\times 10^{-3}\right)$ & $0.52 \pm 0.01$ & $1.03 \pm 0.04^{*}$ & $1.10 \pm 0.07^{*}$ \\
LV/BW $\left(\times 10^{-3}\right)$ & $1.26 \pm 0.04$ & $1.44 \pm 0.05$ & $1.43 \pm 0.08$ \\
\hline
\end{tabular}

Data are mean \pm S.E.M. ${ }^{*} p<0.05 v$ s. N group. $\mathrm{N}$, normoxia; $\mathrm{CNH}$, continuous hypoxia; INH, intermittent hypoxia for $23 \mathrm{~h} /$ day; BW, body weight; RV, right ventricle; $\mathrm{LV}$, left ventricle; RV/BW, relative weight of the RV; LV/BW, relative weight of the LV.

\section{Data analysis}

The results are expressed as means \pm S.E.M. One-way analysis of variance (ANOVA) and subsequent Student-NewmanKeuls test were used for comparison of differences in normaly distributed variables between the groups. Differences between appropriate groups were considered to be statistically significant when the $p$-value was smaler than $0.05(p<0.05)$.

\section{Results}

\section{The effect of hypoxia on body and heart weight}

Body and heart weight parameters of rats kept under normoxia and those adapted for 3 weeks to CNH or INH are summarized in Table 1. Majority of weight parameters were affected by exposure of animals to chronic hypoxia. Hypoxia led to a significant retardation of body growth, which was accompanied by an increase of the heart weight due to hypertrophy of the right ventricles. The $\mathrm{RV}$ weight increased by about $80 \%$ and the ratio $\mathrm{RV} / \mathrm{BW}$ doubled in both $\mathrm{CNH}$ and INH groups of rats.

\section{The effect of hypoxia on $\beta$-adrenoceptors}

Saturation binding experiments (Fig. 1A) performed on crude myocardial membranes indicated that total number 
A

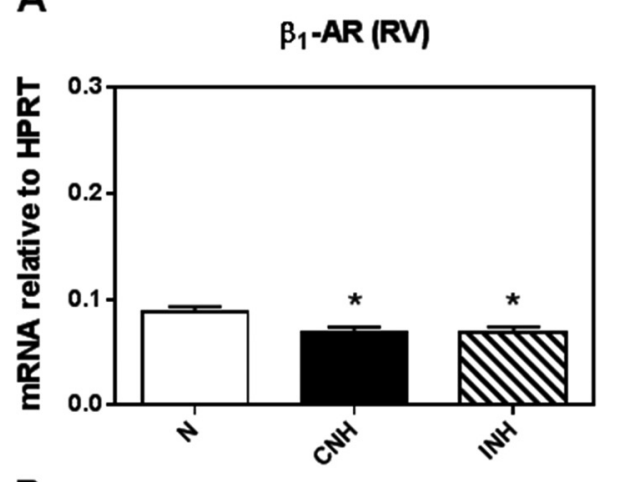

B

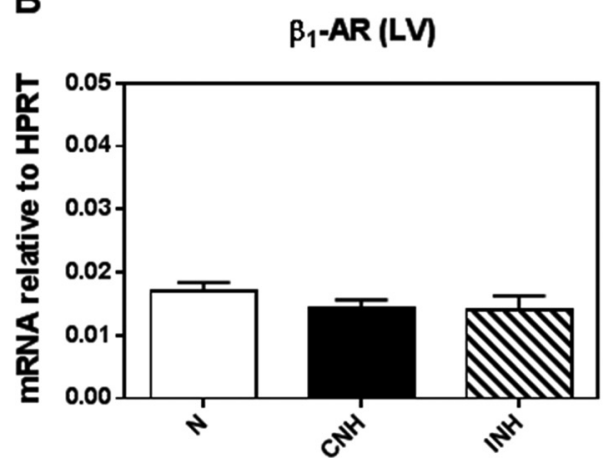

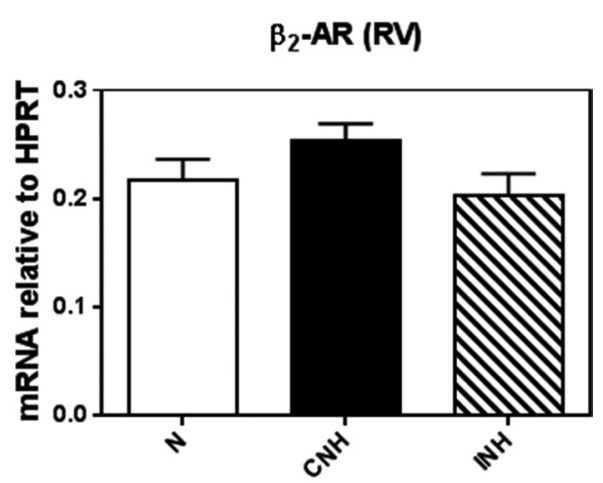

$\beta_{2}$-AR (LV)

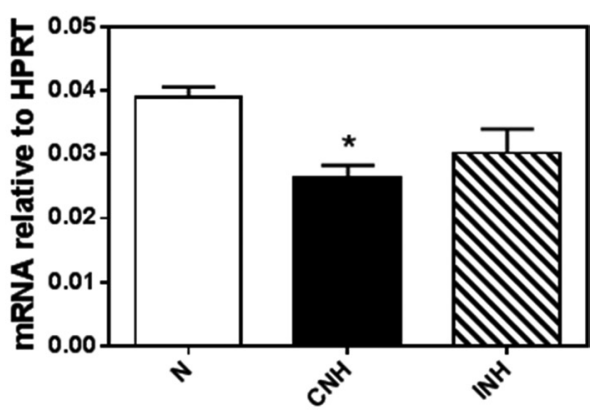

Figure 2. Determination of mRNA levels of $\beta_{1^{-}}$and $\beta_{2^{-}}$ adrenoceptors in the RV (A) and $\mathrm{LV}(\mathbf{B})$ from rats exposed to $\mathrm{CNH}$ (solid bars) or INH (hatched bars) and in corresponding normoxic control (empty bars). Values were expressed relative to expression of the housekeeping gene HPRT. Data represent means ( \pm S.E.M.) of five experiments performed in triplicates. Statistically significant differences $(p<0.05)$ between samples from chronically hypoxic rats (CNH or INH) and corresponding age-matched controls $(\mathrm{N})$ are indicated by the asterisk. For more abbreviations see Fig. 1. of $\beta$-ARs $\left(B_{\max }\right)$ and dissociation constant $\left(K_{D}\right)$ of these receptors in the LV was not affected by any regimen of chronic hypoxia. By contrast, $\mathrm{CNH}$ and $\mathrm{INH}$ reduced the number of $\beta$-ARs in the RV by about $25 \%$ (Table 2). Subsequently, competition binding experiments were conducted to assess the distribution of $\beta$-AR subtypes (Fig. 1B). As indicated in Table 3 , the proportion $\beta_{2}$-AR was increased in RV preparations from rats exposed to hypoxia, but this increase was statistically significant only in the case of $\mathrm{CNH}$. Interestingly, our real-time PCR analyses revealed a significant decrease (by about $20 \%$ ) in the levels of $\beta_{1}$-AR transcripts in $R V$

Table 2. Binding characteristics of $\beta$-ARs

\begin{tabular}{lccc}
\hline & \multicolumn{3}{c}{ Group } \\
\cline { 2 - 4 } & $\mathrm{N}$ & $\mathrm{CNH}$ & $\mathrm{INH}$ \\
\hline$R V$ & & & \\
$\mathrm{~B}_{\max }(\mathrm{fmol} / \mathrm{mg})$ & $29.47 \pm 1.24$ & $21.68 \pm 1.45^{\star}$ & $21.17 \pm 0.65^{\star}$ \\
$\mathrm{K}_{\mathrm{D}}(\mathrm{nM})$ & $0.30 \pm 0.01$ & $0.35 \pm 0.03$ & $0.30 \pm 0.02$ \\
\hline$L V$ & & & \\
$\mathrm{~B}_{\max }(\mathrm{fmol} / \mathrm{mg})$ & $24.64 \pm 0.73$ & $25.62 \pm 0.54$ & $25.78 \pm 1.00$ \\
$\mathrm{~K}_{\mathrm{D}}(\mathrm{nM})$ & $0.41 \pm 0.03$ & $0.38 \pm 0.05$ & $0.37 \pm 0.06$ \\
\hline
\end{tabular}

Data are mean \pm S.E.M. ${ }^{\star} p<0.05$ vs. $\mathrm{N}$ group. $\mathrm{N}$, normoxia; $\mathrm{CNH}$, continuous hypoxia; INH, intermittent hypoxia for $23 \mathrm{~h} /$ day; RV, right ventricle; $L V$, left ventricle; $B_{\max }$, maximal binding; $K_{D}$, dissociation constant. preparations after exposure to hypoxia (Fig. 2). Interestingly, similar drop was found in $\beta_{2}$-AR mRNA in LV preparations from animals affected by $\mathrm{CNH}$.

The effect of hypoxia on the expression of $G$ proteins and adenylyl cyclase

To assess the possible effect of adaptation to hypoxia on myocardial AC signaling, first we investigated the distribu-

Table 3. Distribution and properties of $\beta$-AR subtypes

\begin{tabular}{lccc}
\hline & \multicolumn{3}{c}{ Group } \\
\cline { 2 - 4 } & $\mathrm{N}$ & $\mathrm{CNH}$ & $\mathrm{INH}$ \\
\hline$R V$ & $32.30 \pm 1.41$ & $40.43 \pm 0.29^{\star}$ & $37.80 \pm 3.08$ \\
$\beta_{2}(\%)$ & $2.24 \pm 0.67$ & $2.11 \pm 0.73$ & $1.95 \pm 0.56$ \\
$\mathrm{~K}_{\mathrm{i}} \beta_{2}(\mathrm{nM})$ & $0.51 \pm 0.06$ & $0.68 \pm 0.10$ & $0.52 \pm 0.17$ \\
$\mathrm{~K}_{\mathrm{i}} \beta_{1}(\mu \mathrm{M})$ & & & \\
\hline$L V$ & $34.93 \pm 2.13$ & $29.67 \pm 1.56$ & $30.33 \pm 1.59$ \\
$\beta_{2}(\%)$ & $3.58 \pm 0.71$ & $2.04 \pm 0.52$ & $2.19 \pm 0.53$ \\
$\mathrm{~K}_{\mathrm{i}} \beta_{2}(\mathrm{nM})$ & $1.26 \pm 0.21$ & $0.62 \pm 0.07^{\star}$ & $0.56 \pm 0.02^{\star}$ \\
$\mathrm{K}_{\mathrm{i}} \beta_{1}(\mu \mathrm{M})$ & $1.26 \pm 0$.
\end{tabular}

Data are mean \pm S.E.M., ${ }^{*} p<0.05 v$ s. $\mathrm{N}$ group. $\mathrm{N}$, normoxia; $\mathrm{CNH}$, continuous hypoxia; INH, intermittent hypoxia for $23 \mathrm{~h} /$ day; RV, right ventricle; $L V$, left ventricle; $K_{i}$, inhibition constant. 
tion of the stimulatory $\mathrm{G}$ protein and the dominant isoforms (5 and 6) of cardiac AC in membrane preparations from both the right and left ventricles of rats exposed to chronic hypoxia. Our Western blot analyses (Fig. 3) revealed a pronounced decrease (by about $40-50 \%$ ) in Gsa protein expresion in the RV from animals affected by $\mathrm{CNH}$ or INH, and content of the other tested proteins was not significantly changed by hypoxia.

\section{The effect of hypoxia on adenylyl cyclase activity}

Besides determination of basal AC activity, the enzyme activity was modulated by different stimulatory agents to assess

A

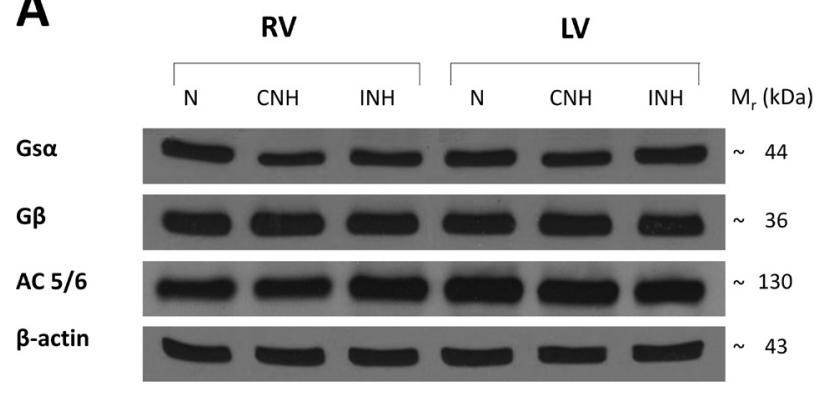

B

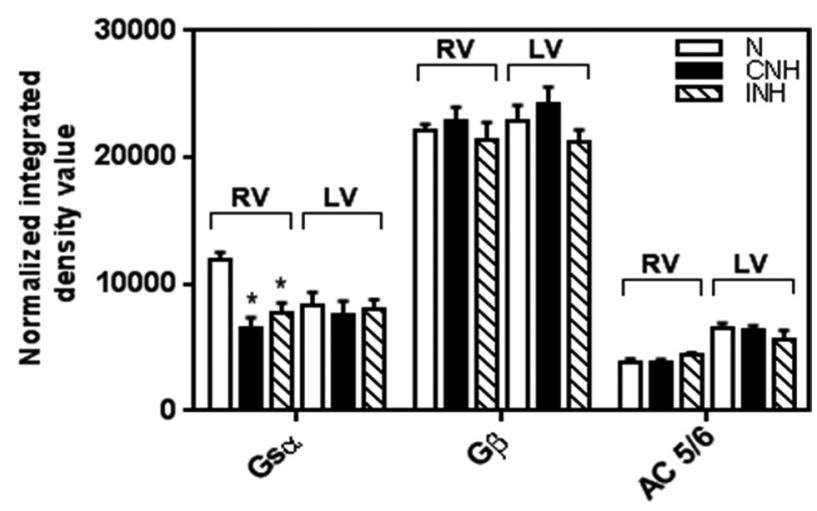

Figure 3. Immunoblot analysis of selected $G$ protein subunits and adenylyl cyclase in right (RV) and left (LV) ventricular preparations from rats exposed to hypoxia ( $\mathrm{CNH}$ and $\mathrm{INH})$ and in corresponding normoxic controls (N). Samples were resolved by SDS-PAGE, transferred onto nitrocelulose membranes, and probed with specific antibodies for $\mathrm{Gs} \alpha$ and $\mathrm{G} \beta$ subunits of $\mathrm{G}$ proteins and $\mathrm{AC}$ isoforms $5 / 6$. After stripping, the blots were reprobed with anti- $\beta$-actin antibody. Representative Western blots are shown (A). The relative protein expression levels of Gsa, G $\beta$ and AC 5/6 were quantified by computer analysis and normalized to the internal standard $\beta$-actin (B). Bar graphs showing normalized integrated optical density values represent means ( \pm S.E.M.) of three separate experiments. Statistically significant differences $(p<0.05)$ between samples from chronically hypoxic rats ( $\mathrm{CNH}$ or INH) and corresponding age-matched controls $(\mathrm{N})$ are indicated by the asterisk. For more abbreviations see Fig. 1.
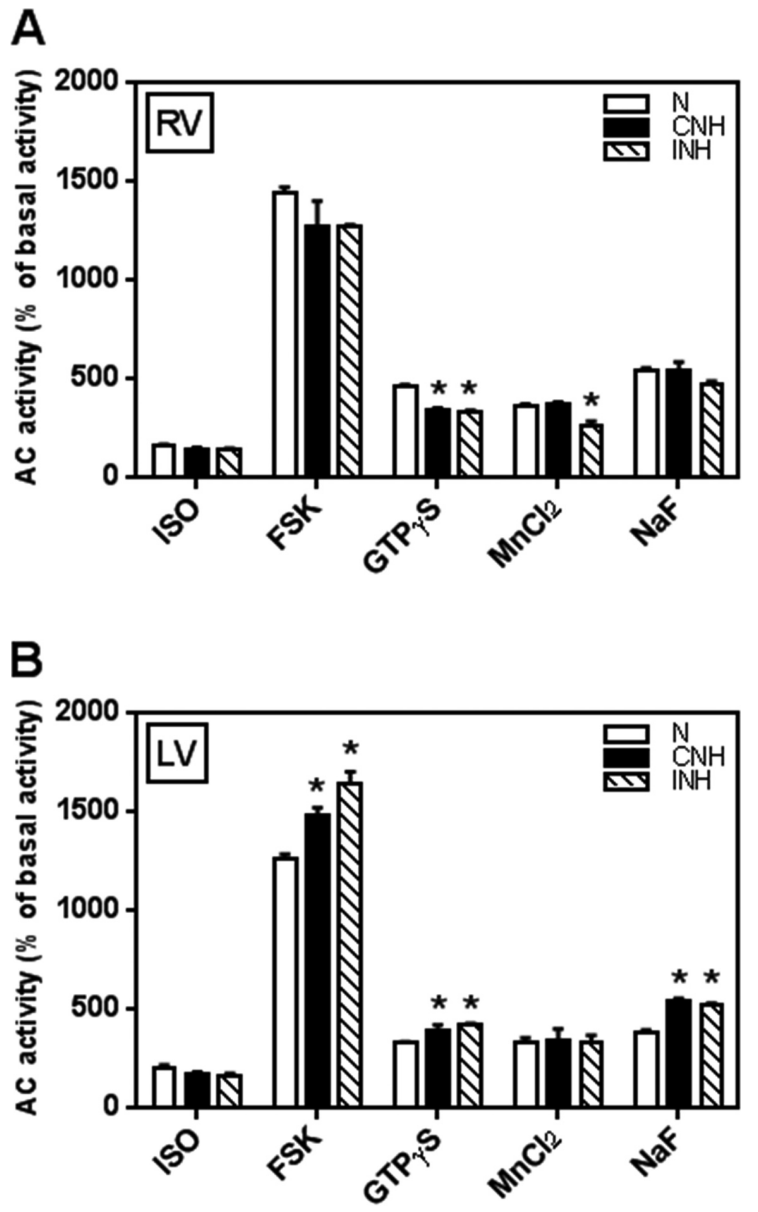

Figure 4. Effect of adaptation to chronic normobaric hypoxia on myocardial adenylyl cyclase activity. AC activity was determined in samples from normoxie rats (N; empty bars) and those adapted to $\mathrm{CNH}$ (solid bars) or INH (hatched bars) using the following stimulators: isoprenaline (ISO), forskolin (FSK), GTP $\gamma \mathrm{S}, \mathrm{MnCl}_{2}$ and $\mathrm{NaF}$. Data are expressed as a percentage of corresponding basal AC activity (100\%). Basal AC activity $(9.98 \pm 0.90 \mathrm{pmol} \mathrm{cAMP} / \mathrm{mg} / \mathrm{min}$ in the $\mathrm{RV}$ and $9.90 \pm 1.05 \mathrm{pmol} \mathrm{cAMP} / \mathrm{mg} / \mathrm{min}$ in the LV) was not affected by exposure to hypoxia. Values represent the mean ( \pm S.E.M.) of five independent measurements performed in duplicates. Statistically significant differences $(p<0.05)$ between samples from chronically hypoxic rats ( $\mathrm{CNH}$ or $\mathrm{INH}$ ) and corresponding age-matched controls (N) are indicated by the asterisk. For more abbreviations see Fig. 1.

functional status of the individual components of the signaling pathway. AC was activated either directly by its cofactor $\mathrm{Mn}^{2+}$ or through stimulation of both the enzyme and Gs protein by forskolin or through stimulation of Gs protein by GTP $\gamma \mathrm{S}$ and by $\mathrm{NaF}$, or through stimulation of $\beta$-ARs by isoprenaline. Although basal AC activity did not significantly differ between different samples, chronic hypoxia apparently affected the ability of Gs protein to regulate the enzyme activity (Fig. 4). Whereas adaptation to hypoxia lowered (by about 
25\%) AC activity stimulated by GTP $\gamma \mathrm{S}$ in RV preparations, thusly modulated activity was increased by about $20 \%$ in LV preparations from $\mathrm{CNH}$ - or INH-adapted rats, compared to the corresponding normoxic controls. Similar enhancement of AC activity in the LV was observed after stimulation by $\mathrm{NaF}$. Forskolin, a potent activator of both the Gs protein and $\mathrm{AC}$, did not significantly reduce the enzyme activity in RV preparations and increased by about $30 \%$ its activity in LV preparations from rats exposed to hypoxia.

\section{Discussion}

The results of our current study indicate that adaptation of adult Wistar rats to different regimens of chronic normobaric hypoxia leads to a significant retardation of body growth, which is accompanied by a pronounced RV hypertrophy. This is in line with many previous observations on similar models (Tual et al. 2006; Laursen et al. 2008; Baandrup et al. 2011; Neckar et al. 2013).

However, the core of the present work is represented by our analysis of $\beta$-adrenergic signaling in ventricular myocardium of rats adapted to cardioprotective $(\mathrm{CNH})$ and nonprotective (INH) regimens of chronic normobaric hypoxia. We first noted a significant reduction in the total number of $\beta$-ARs in RV preparations from both groups of chronically hypoxic rats, which can be attributed to the loss of $\beta_{1}$-ARs because the $\beta_{1} / \beta_{2}$ proportion appreciably decreased. It is known that the total number of myocardial $\beta$-ARs is closely related to catecholamine levels but a selective decrease in $\beta_{1}$-ARs has usually been observed during cardiac hypertrophy. The vast majority of studies focused on this issue were done in the LV (Galinier et al. 1992; Communal et al. 1998; Sethi et al. 2007). For RV hypertrophy, a significant decrease in the total number of $\beta$-ARs was also reported but receptor subtypes were not discriminated in these early studies (Ishikawa et al. 1991; Yoshie et al. 1994; Mardon et al. 1998). Our present data show that RV hypertrophy elicited by exposure to chronic hypoxia exhibits similar changes in the expression of $\beta$-AR subtypes as those found in different types of LV hypertrophy. Moreover, the observed diminution of $\beta_{1}$-ARs at the protein level in the RV after hypoxia was well matched by significantly lower $\beta_{1}$-AR mRNA levels. We have also detected a noticeable drop in $\beta_{2}$-AR mRNA in the LV from rats exposed to $\mathrm{CNH}$, but it was not followed by altered expression of this receptor subtype at the protein level.

Our next experiments revealed that some myocardial $G$ proteins and AC activity were also affected by chronic hypoxia. The observed decreased content of Gsa in the RV after adaptation to $\mathrm{CNH}$ or INH is analogical to lower expression of this protein in the RV affected by hypobaric hypoxia (Guan et al. 2010). Interestingly, differently stimulated AC activity changed in opposite manner in $\mathrm{RV}$ and LV preparations. Although chronic exposure to $\mathrm{CNH}$ and INH did not cause any appreciable changes in basal AC activity, both these hypoxic regimens reduced the enzyme activity stimulated through Gs protein (by GTP $\gamma \mathrm{S}$ ) in the RV and increased this activity in the LV. The reduction of AC activity in the RV may be at least partly explained by the drop in Gs protein level and corresponds well to previously observed derangement of AC in samples of hypertrophied heart (Bohm et al. 1997; Tse et al. 2000; Novotny et al. 2003). Intriguingly, some previous studies exploring the effect of chronic hypoxia on myocardial AC signaling reported similar changes, namely suppression, of this system in both ventricles (Kacimi et al. 1992; Mardon et al. 1998; Leon-Velarde et al. 2001; Hrbasova et al. 2003). It is important to note, hovewer, that severe intermittent hypoxia usually leads to biventricular hypertrophy, the LV being struck to a lesser extent than the RV. On the contrary, no detectable LV hypertrophy was developed by exposure to moderate chronic normobaric hypoxia in our experiments. Under these conditions, it is quite concievable that different changes may occur in both ventricles. Hence, the partially discordant modulation of AC activity by different stimulatory agents in RV and LV from rats exposed to hypoxia may be ascribed to RV hypertrophy leading to derangement of this signaling system. On the other hand, the observed increase in AC activity stimulated by forskolin, GTP $\gamma \mathrm{S}$ and $\mathrm{NaF}$ in the LV after adaptation to $\mathrm{CNH}$ or INH indicates more efficient coupling between Gs protein and AC, which may perhaps somehow participate in the development of a cardioprotective phenotype. Interestingly, the abilility of the $\beta$-AR agonist isoprenaline to stimulate $\mathrm{AC}$ in both ventricles was only slightly reduced which can be ascribed to lesser amount of $\beta$-ARs in the RV and to lower coupling efficiency in the LV. Attenuated $\beta$-adrenergic signaling has been frequently found in cardiac hypertrophy, as well as in other stressful conditions (Bohm et al. 1997; Vatner et al. 1999; Nishizawa et al. 2004).

In conclusion, our present study demonstrates that adaptation to chronic normobaric hypoxia is accompanied by discordant alterations in the myocardial $\beta$-adrenergic signaling system in the right and left ventricles. Exposure to both continuous and intermittent regimen of hypoxia invariably impaired this signaling in the RV but not in the LV, and there was no significant difference between the effects of protective $\mathrm{CNH}$ and nonprotective INH. Although these data do not allow to identify a specific role of $\beta$-ARs and AC signaling in the adaptive process to chronic hypoxia, participation of this signaling system in the development of a cardioprotective phenotype cannot be excluded. Further research is needed to better understand the possible role of $\beta$-adrenergic signaling in cardioprotection. 
Acknowledgement. This study was supported by the Charles University Grant Agency (610612), Czech Science Foundation (303/12/1162) and Ministry of Education, Youth and Sport of the Czech Republic (SVV-260208/2015).

Conflict of interest. There is no conflict of interest.

\section{References}

Baandrup J. D., Markvardsen L. H., Peters C. D., Schou U. K., Jensen J. L., Magnusson N. E., Orntoft T. F., Kruhoffer M., Simonsen U. (2011): Pressure load: the main factor for altered gene expression in right ventricular hypertrophy in chronic hypoxic rats. PLoS One 6, e15859 http://dx.doi.org/10.1371/journal.pone.0015859

Beazely M. A., Watts V. J. (2006): Regulatory properties of adenylate cyclases type 5 and 6: A progress report. (Review). Eur. J. Pharmacol. 535, 1-12 http://dx.doi.org/10.1016/j.ejphar.2006.01.054

Bohm M., Flesch M., Schnabel P. (1997): Beta-adrenergic signal transduction in the failing and hypertrophied myocardium. J. Mol. Med. 75, 842-848 http://dx.doi.org/10.1007/s001090050175

Communal C., Ribuot C., Durand A., Demenge P. (1998): Myocardial beta-adrenergic reactivity in pressure overload-induced cardiac hypertrophy in the rat. Fundam. Clin. Pharmacol. 12, 590-598 http://dx.doi.org/10.1111/j.1472-8206.1998.tb00991.x

El-Armouche A., Zolk O., Rau T., Eschenhagen T. (2003): Inhibitory G-proteins and their role in desensitization of the adenylyl cyclase pathway in heart failure. Cardiovasc. Res. 60, 478-487 http://dx.doi.org/10.1016/j.cardiores.2003.09.014

Galinier M., Senard J. M., Valet P., Drean G., Planat V., Arias A., Tran M. A., Montastruc J. L. (1992): Myocardial hypertrophy, cardiac beta-adrenoceptors and adenylate cyclase activity during sinoaortic denervation in dogs. Br. J. Pharmacol. 105, 341-346 http://dx.doi.org/10.1111/j.1476-5381.1992.tb14256.x

Guan Y., Gao L., Ma H. J., Li Q., Zhang H., Yuan F., Zhou Z. N., Zhang Y. (2010): Chronic intermittent hypobaric hypoxia decreases beta-adrenoceptor activity in right ventricular papillary muscle. Am. J. Physiol. Heart Circ. Physiol. 298, H1267-1272 http://dx.doi.org/10.1152/ajpheart.00410.2009

Guo H. C., Zhang Z., Zhang L. N., Xiong C., Feng C., Liu Q., Liu X., Shi X. L., Wang Y. L. (2009): Chronic intermittent hypobaric hypoxia protects the heart against ischemia/reperfusion injury through upregulation of antioxidant enzymes in adult guinea pigs. Acta Pharmacol. Sin. 30, 947-955 http://dx.doi.org/10.1038/aps.2009.57

Hrbasova M., Novotny J., Hejnova L., Kolar F., Neckar J., Svoboda P. (2003): Altered myocardial Gs protein and adenylyl cyclase signaling in rats exposed to chronic hypoxia and normoxic recovery. J. Appl. Physiol. 94, 2423-2432 http://dx.doi.org/10.1152/japplphysiol.00958.2002

Ihnatovych I., Hejnova L., Kostrnova A., Mares P., Svoboda P., Novotny J. (2001): Maturation of rat brain is accompanied by differential expression of the long and short splice variants of $\mathrm{G}(\mathrm{s})$ alpha protein: identification of cytosolic forms of $\mathrm{G}(\mathrm{s})$ alpha. J. Neurochem. 79, 88-97

http://dx.doi.org/10.1046/j.1471-4159.2001.00544.x

Ishikawa S., Honda M., Yamada S., Morioka S., Moriyama K. (1991): Biventricular down-regulation of beta-adrenergic receptors in right ventricular hypertrophy induced by monocrotaline. Jpn. Circ. J. 55, 1077-1085 http://dx.doi.org/10.1253/jcj.55.1077

Kacimi R., Richalet J. P., Corsin A., Abousahl I., Crozatier B. (1992): Hypoxia-induced downregulation of beta-adrenergic receptors in rat heart. J. Appl. Physiol. 73, 1377-1382

Klevstig M., Manakov D., Kasparova D., Brabcova I., Papousek F., Zurmanova J., Zidek V., Silhavy J., Neckar J., Pravenec M. et al. (2013): Transgenic rescue of defective Cd36 enhances myocardial adenylyl cyclase signaling in spontaneously hypertensive rats. Pflügers Arch. 465, 1477-1486 http://dx.doi.org/10.1007/s00424-013-1281-5

Laursen B. E., Dam M. Y., Mulvany M. J., Simonsen U. (2008): Hypoxia-induced pulmonary vascular remodeling and right ventricular hypertrophy is unaltered by long-term oral Larginine administration. Vascul. Pharmacol. 49, 71-76 http://dx.doi.org/10.1016/j.vph.2008.03.001

Leon-Velarde F., Bourin M. C., Germack R., Mohammadi K., Crozatier B., Richalet J. P. (2001): Differential alterations in cardiac adrenergic signaling in chronic hypoxia or norepinephrine infusion. Am. J. Physiol. Regul. Integr. Comp. Physiol. 280, R274-281

Li H. T., Honbo N. Y., Karliner J. S. (1996): Chronic hypoxia increases beta 1-adrenergic receptor mRNA and density but not signaling in neonatal rat cardiac myocytes. Circulation 94, 3303-3310 http://dx.doi.org/10.1161/01.CIR.94.12.3303

Mader S. L., Downing C. L., Van Lunteren E. (1991): Effect of age and hypoxia on beta-adrenergic receptors in rat heart. J. Appl. Physiol. 71, 2094-2098

Mallet R. T., Ryou M. G., Williams A. G., Jr., Howard L., Downey H. F. (2006): Beta1-Adrenergic receptor antagonism abrogates cardioprotective effects of intermittent hypoxia. Basic Res. Cardiol. 101, 436-446 http://dx.doi.org/10.1007/s00395-006-0599-y

Mardon K., Merlet P., Syrota A., Maziere B. (1998): Effects of 5-day hypoxia on cardiac adrenergic neurotransmission in rats. J. Appl. Physiol. 85, 890-897

Maslov L. N., Naryzhnaia N. V., Tsibulnikov S. Y., Kolar F., Zhang Y., Wang H., Gusakova A. M., Lishmanov Y. B. (2013): Role of endogenous opioid peptides in the infarct size-limiting effect of adaptation to chronic continuous hypoxia. Life Sci. 93, 373-379 http://dx.doi.org/10.1016/j.lfs.2013.07.018

Naghshin J., Rodriguez R. H., Davis E. M., Romano L. C., McGaffin K. R., O'Donnell C. P. (2012): Chronic intermittent hypoxia exposure improves left ventricular contractility in transgenic mice with heart failure. J. Appl. Physiol. 113, 791-798 http://dx.doi.org/10.1152/japplphysiol.00185.2012

Neckar J., Szarszoi O., Koten L., Papousek F., Ost'adal B., Grover G. J., Kolar F. (2002): Effects of mitochondrial K(ATP) modulators 
on cardioprotection induced by chronic high altitude hypoxia in rats. Cardiovasc. Res. 55, 567-575 http://dx.doi.org/10.1016/S0008-6363(02)00456-X

Neckar J., Borchert G. H., Hlouskova P., Micova P., Novakova O., Novak F., Hroch M., Papousek F., Ost'adal B., Kolar F. (2013): Brief daily episode of normoxia inhibits cardioprotection conferred by chronic continuous hypoxia. Role of oxidative stress and BKCa channels. Curr. Pharm. Des. 19, 6880-6889 http://dx.doi.org/10.2174/138161281939131127115154

Nishizawa T., Iwase M., Kanazawa H., Ichihara S., Ichihara G., Nagata K., Obata K., Kitaichi K., Yokoi T., Watanabe M. et al. (2004): Serial alterations of beta-adrenergic signaling in dilated cardiomyopathic hamsters: possible role of myocardial oxidative stress. Circ. J. 68, 1051-1060 http://dx.doi.org/10.1253/circj.68.1051

Novotny J., Bourova L., Kolar F., Svoboda P. (2001): MembraneBound and cytosolic forms of heterotrimeric $G$ proteins in young and adult rat myocardium: influence of neonatal hypoand hyperthyroidism. J. Cell. Biochem. 82, 215-224 http://dx.doi.org/10.1002/jcb.1157

Novotny J., Hrbasova M., Kolar F., Svoboda P. (2003): Cardiomegaly induced by pressure overload in newborn rats is accompanied by altered expression of the long isoform of $\mathrm{G}(\mathrm{s})$ alpha protein and deranged signaling of adenylyl cyclase. Mol. Cell Biochem. 245, 157-166 http://dx.doi.org/10.1023/A:1022828430565

Okruhlicova I., Ravingerova T., Pancza D., Tribulova N., Stetka R. (1999): The role of adenylate cyclase in ischemic preconditioning in the rat heart: a cytochemical study. Gen. Physiol. Biophys. 18 (Suppl. 1), 44-47

Ostadal B., Kolar F. (2007): Cardiac adaptation to chronic highaltitude hypoxia: beneficial and adverse effects. Respir. Physiol. Neurobiol. 158, 224-236 http://dx.doi.org/10.1016/j.resp.2007.03.005

Pei J. M., Yu X. C., Fung M. L., Zhou J. J., Cheung C. S., Wong N. S., Leung M. P., Wong T. M. (2000): Impaired G(s)alpha and adenylyl cyclase cause beta-adrenoceptor desensitization in chronically hypoxic rat hearts. Am. J. Physiol. Cell Physiol. 279, C1455-1463

Pelouch V., Kolar F., Ost'adal B., Milerova M., Cihak R., Widimsky J. (1997): Regression of chronic hypoxia-induced pulmonary hypertension, right ventricular hypertrophy, and fibrosis: effect of enalapril. Cardiovasc. Drugs Ther. 11, 177-185 http://dx.doi.org/10.1023/A:1007788915732

Sethi R., Saini H. K., Guo X., Wang X., Elimban V., Dhalla N. S. (2007): Dependence of changes in beta-adrenoceptor signal transduction on type and stage of cardiac hypertrophy. J. Appl. Physiol. 102, 978-984

http://dx.doi.org/10.1152/japplphysiol.00921.2006

Tse J., Huang M. W., Leone R. J., Weiss H. R., He Y. Q., Scholz P. M. (2000): Down regulation of myocardial beta1-adrenoceptor signal transduction system in pacing-induced failure in dogs with aortic stenosis-induced left ventricular hypertrophy. Mol. Cell. Biochem. 205, 67-73 http://dx.doi.org/10.1023/A:1007085027234

Tual L., Morel O. E., Favret F., Fouillit M., Guernier C., Buvry A., Germain L., Dhonneur G., Bernaudin J. F., Richalet J. P. (2006): Carvedilol inhibits right ventricular hypertrophy induced by chronic hypobaric hypoxia. Pflügers Arch. 452, 371-379 http://dx.doi.org/10.1007/s00424-006-0058-5

Vatner D. E., Asai K., Iwase M., Ishikawa Y., Shannon R. P., Homcy C. J., Vatner S. F. (1999): Beta-adrenergic receptor-G proteinadenylyl cyclase signal transduction in the failing heart. Am. J. Cardiol. 83, 80H-85 http://dx.doi.org/10.1016/s0002-9149(99)00266-0

Waskova-Arnostova P., Elsnicova B., Kasparova D., Sebesta O., Novotny J., Neckar J., Kolar F., Zurmanova J. (2013): Right-to-left ventricular differences in the expression of mitochondrial hexokinase and phosphorylation of Akt. Cell. Physiol. Biochem. 31, 66-79 http://dx.doi.org/10.1159/000343350

Yoshie H., Tobise K., Onodera S. (1994): Intraventricular changes in the beta-adrenoceptor-adenylate cyclase system of the rat heart with the progress of monocrotaline-induced right ventricular hypertrophy. Jpn. Circ. J. 58, 855-865 http://dx.doi.org/10.1253/jcj.58.855

Zhuang J., Zhou Z. (1999): Protective effects of intermittent hypoxic adaptation on myocardium and its mechanisms. Biol. Signals Recept. 8, 316-322

http://dx.doi.org/10.1159/000014602

Received: July 14, 2015

Final version accepted: October 29, 2015

First published online: February 18, 2016 